\title{
Can Prenatal and Postnatal Cell Phone Exposure Increase Adverse Maternal, Infant and Child Outcomes?
}

\section{A exposição pré-natal e pós-natal a telefones celulares pode aumentar os resultados adversos para mães, bebês e crianças?}

\author{
Farzaneh Ashrafinia10 Somayeh Moeindarbari2®

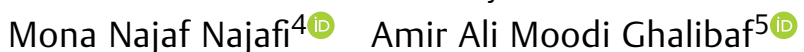 \\ Parisa Razmjouei ${ }^{30}$ Masumeh Ghazanfarpour ${ }^{2}$ (1) \\ Fatemeh Abdi ${ }^{6}$ (1)
}

\footnotetext{
${ }^{1}$ Department of Midwifery, School of Nursing and Midwifery, Kerman University of Medical Sciences, Kerman, Iran

${ }^{2}$ Student Research Committee, Kerman University of Medical Sciences, Kerman, Iran

${ }^{3}$ Department of Gynecology and Obstetrics, Shahid Faghihi Hospital, Shiraz University of Medical Sciences, Shiraz, Iran

${ }^{4}$ Clinical Research Unit, Mashhad University of Medical Sciences,

Mashhad, Iran

${ }^{5}$ Student Research Committee, Faculty of Medicine, Mashhad

University of Medical Sciences, Mashhad, Iran

${ }^{6}$ Non-communicable Diseases Research Center, Alborz University of Medical Sciences, Karaj, Iran
}

\author{
Address for correspondence Masumeh Ghazanfarpour, Kerman \\ University of Medical Sciences, Medical University Campus, Haft-Bagh \\ Highway, Kerman, Iran \\ (e-mail: masumeh.ghazanfarpour@yahoo.com).
}

Rev Bras Ginecol Obstet 2021;43(11):870-877.

\begin{abstract}
Keywords

- cell phone

- maternal outcome

- infant outcomes
\end{abstract}

Objective To determine the association between maternal mobile phone use and adverse outcomes in infants, children, and mothers.

Method In March 202, we conducted a search on the MEDLINE, Embase, and Scopus databases. Data extraction and an assessment of the quality of the studies were performed by two authors. The quality of the studies was assessed using the checklist of the Newcastle-Ottawa scale.

Results Studies assessing behavioral problems in infants aged 6 to 18 months reported null findings. However, an increased risk of emotional and behavioral disorders was observed in children aged between 7 and 11 years whose mothers had been exposed to cell phones. The findings regarding the association between maternal cell phone exposure and adverse outcomes in children aged 3 to 5 are controversial. A study found a significant association between the call time $(p=0.002)$ or the history of mobile phone use (in months) and speech disorders in the children $(p=0.003)$. However, another study found that maternal cell phone use during pregnancy was not significantly associated with child psychomotor and mental received

December 16, 2020

accepted

August 8, 2021
DOI https://doi.org/ 10.1055/s-0041-1736173. ISSN $0100-7203$
(C) 2021. Federação Brasileira de Ginecologia e Obstetrícia. All rights reserved.

This is an open access article published by Thieme under the terms of the Creative Commons Attribution License, permitting unrestricted use, distribution, and reproduction so long as the original work is properly cited. (https://creativecommons.org/licenses/by/4.0/)

Thieme Revinter Publicações Ltda., Rua do Matoso 170, Rio de Janeiro, RJ, CEP 20270-135, Brazil 


\section{Resumo}

\author{
Palavras-chave \\ - celular \\ - resultado materno \\ - resultados em \\ crianças
}

developments. Inconclusive results were observed about the adverse outcomes in fetuses, such as fetal growth restriction or $t$ scores for birth weight in cell phone users as opposed to non-users. On the contrary, the children of mothers who were cell phone users had a lower risk of scoring low on motor skills. Similar results were observed regarding the adverse outcomes of cell phone use in infants, such as fetal growth restriction or low birth weight, and the risk of preeclampsia was lower among subjects with medium and high cell phone exposure, as opposed to those with low exposure. Conclusion Studies on behavioral problems have reported different postnatal results, such as null findings among infants and a positive association in children.

Objetivo Determinar a associação entre o uso de telefone celular pela mãe e os resultados adversos em recém-nascidos crianças e mães.

Método Em março de 2020 realizou-se uma pesquisa nas bases de dados MEDLINE, Embase e Scopus. A extração de dados e avaliação da qualidade dos estudos foram realizadas por dois autores. A qualidade dos estudos foi avaliada por meio da lista de verificação da escala Newcastle-Ottawa.

Resultados Estudos que avaliavam problemas comportamentais em recém-nascidos de 6 a 18 meses relataram resultados nulos. No entanto um risco aumentado de transtornos emocionais e comportamentais foi observado em crianças de 7 a 11 anos de idade cujas mães foram expostas a telefones celulares. Os resultados relacionados à associação entre a exposição materna a celulares e resultados adversos em crianças de 3 a 5 anos são controversos. Um estudo encontrou associação significativa entre o tempo de ligação $(p=0.002)$ ou o histórico de uso de celular (em meses) e distúrbios de fala nas crianças $(p=0.003)$. No entanto outro estudo descobriu que o uso de telefone celular pela mãe durante a gravidez não estava significativamente associado ao desenvolvimento psicomotor e mental da criança. Resultados inconclusivos foram observados com relação aos resultados adversos de fetos como restrição de crescimento intrauterino ou valores de t para peso ao nascer em usuárias de telefone celular em oposição a não usuárias. Pelo contrário os filhos de mães usuárias de telefone celular apresentaram menor risco de pontuação baixa em habilidades motoras. Resultados semelhantes foram observados com relação a resultados adversos em recém-nascidos como restrição de crescimento intrauterino ou valores de peso ao nascere o risco de pré-eclâmpsia foi menor em indivíduos com exposição média e alta a celulares em oposição àqueles com baixa exposição.

Conclusão Estudos sobre problemas comportamentais relataram resultados diferentes no pós-natal como achados nulos em recém-nascidos e associação positiva em crianças.

\section{Introduction}

One of the most important devices that has seen a dramatic growth in recent years is the cell phone. ${ }^{1}$ Research shows that cell phones could expose a user to radiofrequency electromagnetic fields (RF-EMFs). ${ }^{2}$ Excessive mobile phone use in Japan is not limited to students, and can be used in adult women, even during the prenatal period. ${ }^{3}$ Cell phone based interventions and monitoring are used in the field of maternal and maternity health care. ${ }^{4}$

Research has shown the safety of the short-term exposure to RF-EMFs in adults, while long term exposure have not been conclude. Fetuses and children, as opposed to adults, may be more vulnerable to the effects of the long-term exposure to RF-EMFs on human health. ${ }^{5}$ Studies have questioned the theory of the thermal effect induced by cell phones because the rate of absorption of cell phone RF by the pregnant uterus is not high enough to raise the body temperature. ${ }^{6-13}$ There is still ongoing research on the nonthermal effects of RF radiation (RFR).

According to a study ${ }^{6}$ conducted in rats, the exposure of mothers to cell phones may be associated with behavioral complications in the offspring, though no side effects have 
been reported. There are divergent epidemiological findings regarding the prenatal exposure of mothers to cell phones and null results in the earlier stages of an infant's life; however, a positive relationship has been reported at later stages, except for a study that employed a prospective questionnaire. ${ }^{7}$ Researchers have explored the health consequences of the exposure to cell phone RF, but there is a need for further studies to draw definitive conclusions. ${ }^{5}$ Accordingly, a systematic review is needed to summarize and scrutinize all the findings in this field to help the clinical practice and reveal the gap in the existing evidence.

\section{Methods}

\section{Literature Search and Selection Criteria}

In March 2020, a literature search was conducted on the MEDLINE, Embase, and Scopus databases using the terms radiofrequency, $R F$, RF-EMFs, phone, mobile phone, cell phone, electromagnetic field, electromagnetic waves, EMF, EMW, children, and behavior. After reading the title and abstract of all studies during the screening stage, all full-length articles were carefully reviewed by two independent researchers to check the inclusion and exclusion criteria. Any disagreement between the two researchers was settled through consensus. The inclusion criterion was any study on the association of maternal cell phone use and infant and maternal outcomes.

\section{Data Extraction and Statistical Analysis}

The following data was extracted from the studies and recorded in a form designed by the research team: author, year, country, study design, population, study duration, source of information, disorder diagnosis instrument, outcomes (relative risk [confidence interval, $\mathrm{CI}$ ]), and covariates (-Table 1). The necessary adjustments were made, and disagreements were resolved by discussion to reach a decision.

\section{Quality Assessment of Studies}

The quality of the studies was assessed using NewcastleOttawa Scale (NOS) checklist, which investigates the selection criteria of cohorts (representativeness of the exposed cohort, selection of the non-exposed cohort, ascertainment of exposure, demonstration that the outcome of interest was not present at the beginning of the study), the comparability, and the outcome (-Table $\mathbf{2}$ ).

\section{Results}

\section{Maternal Cell Phone Use and Behavioral Problems in Children}

In a study by Sudan et al., ${ }^{8}$ mothers of 7-year-old children were asked to complete a questionnaire that investigated prenatal and postnatal cell phone exposure. The children were then followed up until the age of 11 , and the authors found an increased risk of developing emotional and behavioral problems by that age.
An odds ratio (OR) of 1.58 (95\%Cl: 1.34 to 1.86 ) when children were exposed to both prenatally and used cellphones at age 7 years, OR of 1.41 (95\%CI: 1.20 to 1.66) for prenatal exposure and an OR of 1.36 (95\%CI: 1.14 to 1.63 ) for the postnatal exposure. ${ }^{8}$

Divan et al., ${ }^{9}$ in a study with mothers of 13,159 7-year-old children, observed a significant association between behavioral problems in children and prenatal cell phone exposure. The highest $\mathrm{OR}$ for behavioral problems was observed in children who had both prenatal and postnatal cell phone exposure (OR $=80 ; 95 \% \mathrm{CI}: 1.45$ to 2.23 ), followed by prenatal exposure alone ( $\mathrm{OR}=1.54 ; 95 \% \mathrm{CI}$ : 1.32 to 1.81 ) and postnatal exposure alone $(\mathrm{OR}=1.18$; $95 \% \mathrm{CI}$ : 1.01 to 1.38$)$. To account for additional confounders (including variables that show the mother's attention to the health of the child in the early stages of life), Divan et al. ${ }^{10}$ conducted a largescale study on 28,745 mothers of 7 -year-old children. The results indicated a connection between behavioral problems and exposure during both periods. The OR was of 1.5 (95\%CI: 1.4 to 1.7) for the prenatal and postnatal exposure, of 1.4 (95\%CI: 1.2 to 1.5 ) for the prenatal exposure alone, and of 1.2 (95\%CI: 1.0 to 1.3 ) for the postnatal exposure alone. ${ }^{10}$ Zarei et al. ${ }^{11}$ conducted a study on mothers of healthy children aged 3 to 5 years, and found a significant association between call time $(p=0.002)$ or the history of mobile phone use (in months) and speech disorders in children $(p=0.003)$. However, the strength of the association between cordless phone use $(p=0.528)$ and speech disorders was weak. ${ }^{11}$

Contrary to the aforementioned studies, Papadopoulo et al., ${ }^{4}$ in a prospective study on 45,389 mother-child pairs, reported that children whose mothers were cell phone users in the early months of pregnancy had a lower risk of developing low motor skills and $17 \%$ had a lower adjusted risk of developing sentence complexity $(\mathrm{OR}=0.83 ; 95 \% \mathrm{CI}$ : $0.77,0.89$ ) at the age of 3 , as opposed to children whose mothers did not use cell phones, but the difference was not observed in 5-year-old children. An association was also found between maternal cell phone use and the development of low communication skills in children. The risk was $13 \%$, $22 \%$ and $29 \%$ lower by low, medium and high maternal cell phone use. ${ }^{4}$

In another study, ${ }^{7}$ maternal cell phone use during pregnancy was found to be significantly associated with the psychomotor development index (PDI) and mental development index (MDI) in infants and children at 6, 12, 24, and 36 months of age. However, in children exposed to high maternal blood lead level (BLL) in utero, an increased risk of low MDI was observed with an increasing number of calls a day. According to Vrijheid et al., ${ }^{12}$ the children of cell phone users had higher mental development scores and lower psychomotor development scores compared with those of non-users at 14 months of age. However, the difference was slight. A significant difference was only observed between the children of compulsive users and those of non-users. The highest decrease in psychomotor scores (5.6 points [95\% confidence interval 10.7 to 0.5 ]) was reported by Vrijheid et al. ${ }^{12}$ Divan et al., ${ }^{13}$ in a study with more than 41 thosusand singletons, found no significant association between 


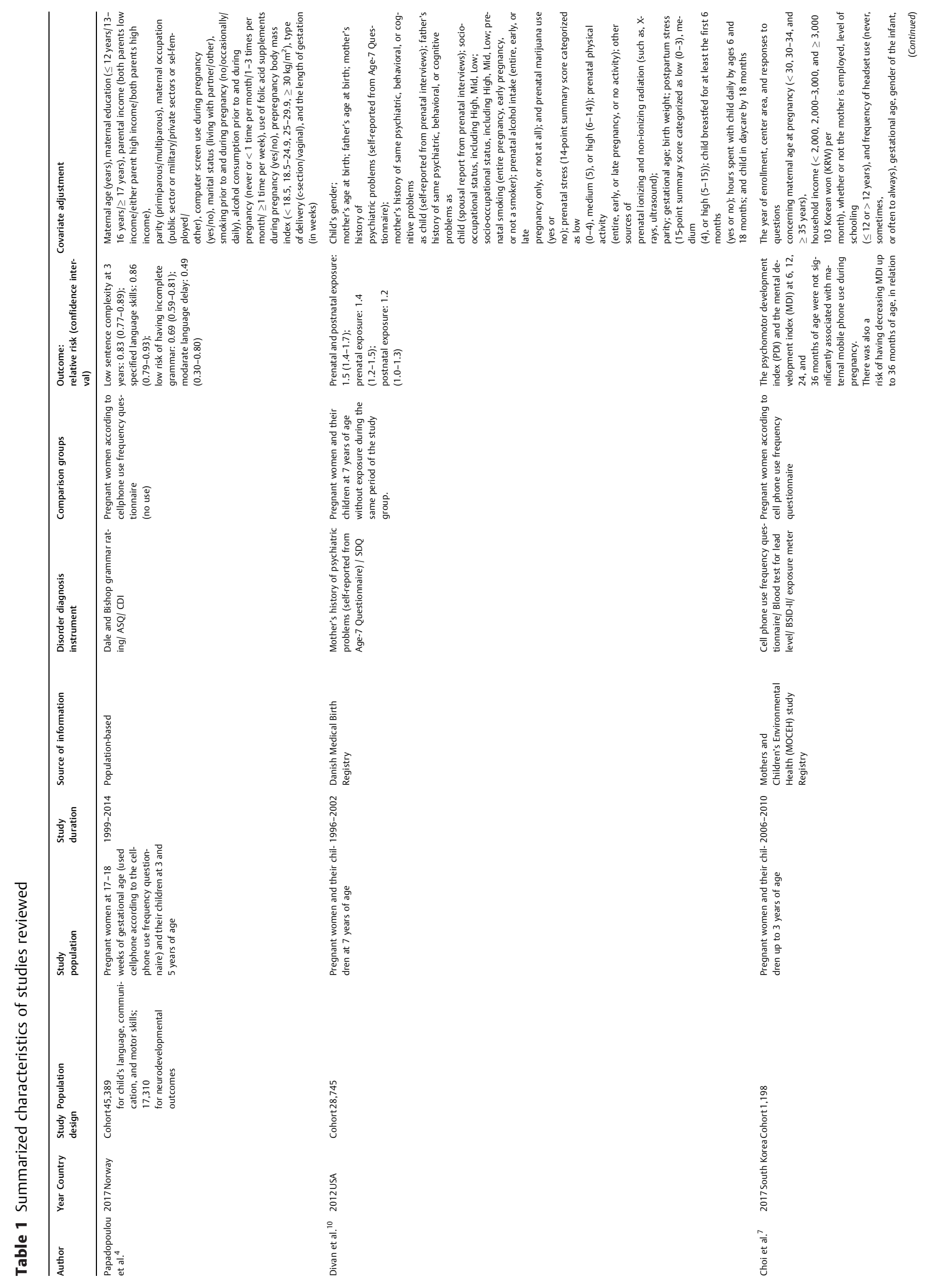




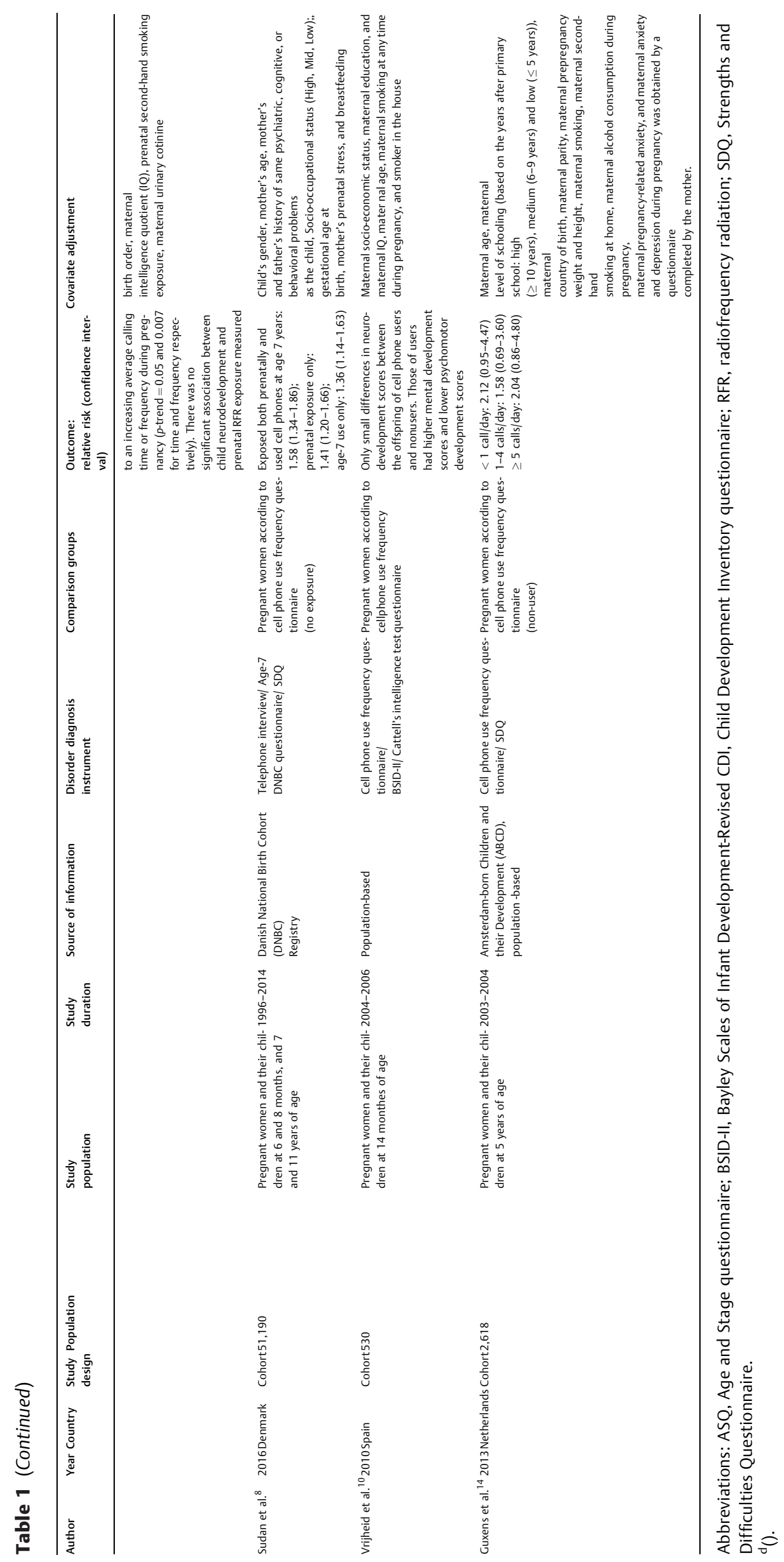


prenatal cell phone use and motor or cognitive/language developmental delays. The adjusted ORs were of 0.8 (95\%CI: 0.7 to 1.0 ) and 1.1 (95\%CI: 0.9 to 1.3 ) for cognitive/language in children 6 and 18 months old, respectively. The adjusted ORs were of 0.9 (95\%CI: 0.8 to 1.1 ) and of 0.9 (95\%CI: 0.8 to 1.0 ) for motor development delay in children 6 and 18 months old, respectively. Guxens et al., ${ }^{14}$ in a cohort study with 2,618 children, reported a non-significant association between behavioral problems and the number of calls $(\mathrm{OR}=2.12$; $95 \% \mathrm{CI}$ : 0.95 to 4.74 for $<1 \mathrm{call} / \mathrm{day}$; $\mathrm{OR}=1.58 ; 95 \% \mathrm{CI}$ : 0.69 to 3.60 for 1 to 4 calls/day; and OR $=2.04 ; 95 \%$ CI: 0.86 to 4.80 for $\geq 5$ calls/day).

\section{The Effect of Maternal Cell Phone Use on Migraines and Headaches in Children}

In a study conducted by Sudan et al., ${ }^{15}$ the OR was of 30\% (95\%CI: 1.01 to 1.68 ) for migraines, and of $32 \%$ (95\%CI: 1.23 to 1.40) for headache-related symptoms. It was higher for children with prenatal or postnatal exposure than for those with no exposure. Moreover, the OR was of 1.32 (95\%CI:1.07 to 1.63 ), 1.77 (95\%CI: 1.23 to 2.55 ), and 1.88 (95\%CI: 1.21 to 2.77 ) for migraines (never used hands-free device, rarely used hands-free device, and often used hands-free device in children according to mother's report of cell phone use). ${ }^{15}$

\section{Congenital Malformation}

According to Baste et al., ${ }^{16}$ the risk of congenital malformation was lower in children with medium (risk ratio [RR] $=0.99$; $95 \% \mathrm{CI}$ : 0.92 to 1.06 ) and high cell phone exposure $(\mathrm{RR}=1.01 ; 95 \% \mathrm{Cl}: 0.92$ to 1.11$)$.

\section{Perinatal Mortality}

In the study by Baste et al., ${ }^{16}$ the risk of perinatal mortality was close to null in subjects with medium $(R R=0.89 ; 95 \% \mathrm{CI}$ : 0.73 to 1.08$)$ and high cell phone exposure $(R R=0.80 ; 95 \% \mathrm{CI}$ : 0.60 to 1.06$)$.

\section{Low Birth Weight}

Still in the study by Baste et al., ${ }^{16}$ the risk of low birth weight was close to null in subjects with medium $(R R=1.01 ; 95 \% \mathrm{CI}$ : 0.92 to 1.10$)$ and high cell phone exposure $(\mathrm{RR}=1.02 ; 95 \% \mathrm{CI}$ : 0.91 to 1.15$)$. Lu et al. ${ }^{3}$ compared birth weight between mothers who excessively or ordinarily utilized cell phones and found that the newborns of mothers who used cell phones excessivelly had a significantly lower birth weight $(p=0.03)$. However, no significant difference was observed between the two groups regarding the proportion of lowbirth weight newborns $(p=0.6) .^{3}$

\section{Preterm Birth}

Still in the study by Baste et al., ${ }^{16}$ the risk of preterm birth was near null in subjects with medium $(\mathrm{RR}=0.99 ; 95 \% \mathrm{CI}$ : 0.92 to 1.06$)$ and high cell phone exposure $(R R=1.01 ; 95 \% \mathrm{CI}$ : 0.93 to 1.11$).{ }^{16}$ However, no statistically significant differences were observed the groups of excessive and ordinary users of cell phones regarding the ratio of preterm birth $(p=0.06)$.

\section{Small for Gestational Age Newborns}

Still in the study by Baste et al., ${ }^{16}$ the risk of having small for gestational age (SGA) newborns was close to null in subjects with medium ( $R R=1.02 ; 95 \% \mathrm{CI}: 0.96$ to 1.09$)$ and high ( $R R$ $=1.03$; $95 \%$ CI: 0.95 to 1.11 ) cell phone exposure compared with those with low exposure. Lu et al. ${ }^{3}$ compared the ordinary and excessive use of cell phone by mothers, and reported that, in the latter group, the rates of lower birth weight and chest circumference $(p=0.05)$ were significantly higher than those of the former group. However, no statistically significant differences were observed between the two groups regarding the birth height $(p=0.792)$ and birth head circumference $(p=0.06){ }^{3}$

\section{Preeclampsia}

Still in the study by Baste et al., ${ }^{16}$ the risk of preeclampsia was lower among subjects with medium $(\mathrm{RR}=0.89 ; 95 \% \mathrm{CI}$ : 0.82 to 0.96$)$ and high ( $R R=0.89 ; 95 \% \mathrm{CI}$ : 0.80 to 0.98$)$ cell phone exposure as opposed to those with low exposure. ${ }^{16}$

\section{Discussion}

Divan et al. ${ }^{7}$ found a significant association between behavioral problems at the age of 7 and prenatal and postnatal cell phone exposure. The results of a subsequent study by the same authors ${ }^{10}$ on a larger sample size, conducted in 2012 after the consideration of additional confounders, showed that the previous finding was not coincidental. However, the OR was still smaller and remained significant. At ages as early as 6 to 12 months, no significant association was observed between prenatal cell phone use and motor or cognitive/language developmental delays. ${ }^{13}$

There are many biological mechanisms behind the impact of in utero RFR-exposure on the brain of an infant. Exposure to RFR leads to energy transfer, thus elevating the permeability of the blood-brain barrier to macromolecules. The immature blood-brain barrier of the fetus can be susceptible even lower RFR energy induced by the mother's mobile phone use or the act of holding of the cell phone near the body that can affect the fetal brain. The lead in the mother's blood passes through the blood-placental barrier and penetrates the cord blood. The increased permeability of the blood-placental barrier due to RFR energy can result in the transmission of a high dose of lead. High levels of lead, a neurotoxin, in the cord blood can be transmitted to the fetal brain and provoke neurodevelopment complications. The release of melatonin by the pituitary gland can be impaired by RFR exposure. Also, the release of melatonin by the pituitary gland can be impaired by RFR exposure. The fetal stem cells, such as future neuronal cells, may be influenced by RFR exposure as well (Bellieni and Pinto, 2012). ${ }^{17}$ Interestingly, there is no study to date that can confirm any of these hypotheses. ${ }^{7}$

Wired-in hands-free kits (HFKs) can considerably reduce RFR exposure to the head, ${ }^{18}$ which is inconsistent with the results of Sudan et al., ${ }^{13}$ that found that the use of a handsfree device during pregnancy was associated with the increased risk. The highest ORs for migraines were found in the 


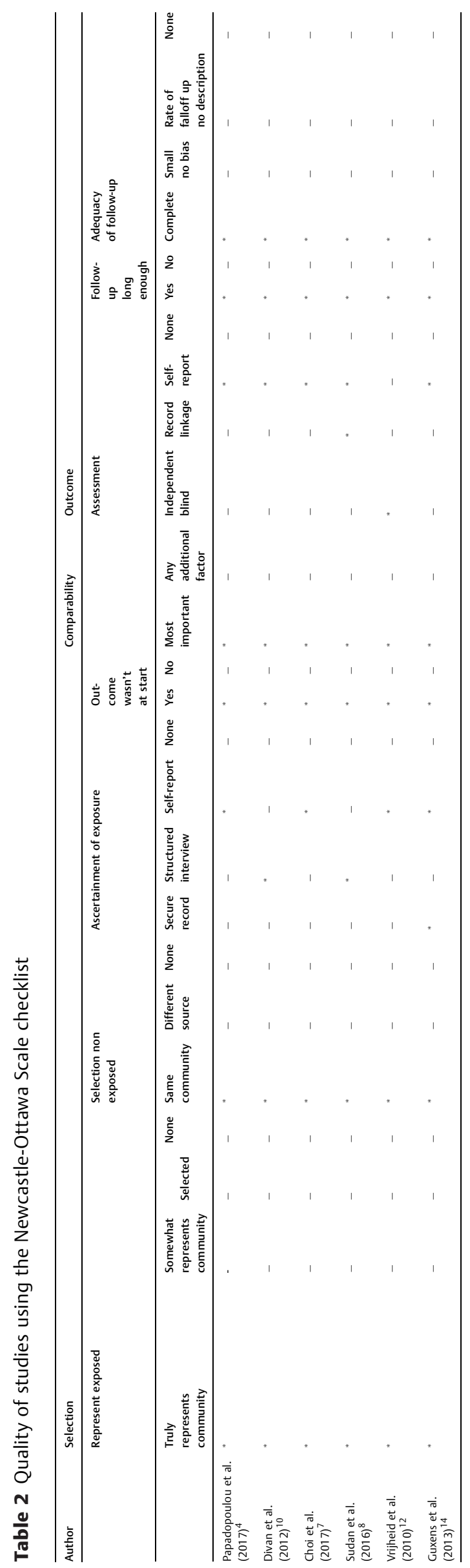

groups that often used hands-free devices, followed by those who "rarely used hands-free devices" and "never used hands-free devices." 15 However, these differences between studies may be due to the fact that several factors that have been related to the infant, mother, or environmental factors can affect fetal growth, birth weight and gestation length.

According to a study by Ferraro et al., ${ }^{19}$ college students who text excessively had higher levels of depression and anxiety and poor sleep quality. According to Lu et al., ${ }^{3}$ pregnant women who used mobile phones in excess often slept later than those who used cell phones ordinarily. They suggested that anxiety, depression, and sleep problems, as indirect factors, may contribute to low birth weight. ${ }^{3}$ Therefore, future research should should have sufficiently large samples to conduct a path analysis.

The present study has some strengths. Some of the previous research had long follow-up periods and large samples, such as the study by Papadopoulou et al., ${ }^{4}$ which monitored 45,389 mother-child pairs over a period of 5 years. Their research was the largest on the association between maternal cell phone use and neurodevelopmental outcomes in children. ${ }^{4}$ There are many shortcomings in the present systematic review that need to be addressed. First, the sample size of some studies was relatively small. ${ }^{3}$ In several studies, no significant association was observed. In the study by Lu et al., ${ }^{3}$ excessive cell phone use during pregnancy was not associated with low birth weight. However, there were only 16 infants with low birth weight in the study. ${ }^{3}$ Therefore, the study may not have sufficient power to appropriately assess the association between excessive mobile phone use and low infant birth weight. Excessive mobile phone may be a risk factor for infant emergency transport but this, conclusion was conducted to be based on only 10 case ( 7 cases in ordinary cell phone users group and 3 cases in excessive cell phone users group). ${ }^{3}$ The small sample size increases the chance of a false-positive (type-I) error. Second, all information gathered was self-reported by the participants, which may understimate the reliability of the responses. ${ }^{3}$ The third limitation was related to the possibility of a recall bias, that is, the mother could have underestimated or overestimated the amount of cell phone use during pregnancy. However, a previous study ${ }^{14}$ has shown that retrospectively reported phone calls are usually slightly underestimated. Also, pregnancy has a strong effect on the memories of mothers, so they are eager to remember accurately their behaviors within these unique days. ${ }^{8}$ The fourth limitation is that almost all studies included in this systematic review reported the number of phone calls as an estimation. It seems that other factors like the extent of RF-EMF exposure are also important. Adverse in maternal, infant and child also depends on factors such as the duration of calls, the use of hands-free equipment, the communication system, and the frequency band. ${ }^{14}$ The use of cell phones was also associated with smoking status, so that a higher level of smoking in the subjects link with to more calls. ${ }^{19}$ However, one of the studies ${ }^{20}$ has also assessed confounding variables. The fifth limitation is that almost all studies measure child neurodevelopment through subjective assessments of 
parental reports, except for one study ${ }^{7}$ that had used expert examiners. Moreover, one study ${ }^{4}$ adjusted important potential confounders by including sociodemographic characteristics, maternal personality, and psychological factors. However, it is unlikely that studies that did not report unmeasured confounding factors (such as, genetic or lifestyle factors) have affected our findings. Besides, the sample of unexposed groups was relatively small in most of studies. ${ }^{7,12,14}$ Future studies should consider a sufficiently large sample of unexposed groups, although the rate of cell phone use is rapidly increasing. ${ }^{21}$ The distribution of variables such as center area (one of the centers including: Cheonan, Seoul, Ulsan), age, and income was different regarding the subjects in the study by Choi et al., ${ }^{7}$ but other general characteristics were identical. Finally, missing data was considered moderate, for example 33\% of children had missing information related to emotional and behavioral problems at the age of 11.8

\section{Conclusion}

Studies on behavioral problems have reported different postnatal results, such as null findings among infants and a positive association in children.

\section{Contributors}

All authors participated in the concept and design of the study, as well as in the analysis and interpretation of data, draft or revision of the manuscript, and they have approved the manuscript as submitted. All authors are responsible for the reported research.

\section{Conflict of Interests}

The authors have no conflict of interests to declare.

\section{References}

1 Sumarlam S, Marmanto S. Politeness and Impoliteness in Directives: A Study on the Students-Lecturers Interaction. 2018

2 Tanvir S, Thuroczy G, Selmaoui B, Pires-Antonietti VS, Sonnet P, Lévêque $\mathrm{P}$, et al., editors. Effects of cell phone radiofrequency exposure on the human cytochrome P450 reductase. Journées Scientifiques URSI-France JS'12 “Champs électromagnétiques: de la dosimétrie à la santé humaine". 2012

3 Lu X, Oda M, Ohba T, Mitsubuchi H, Masuda S, Katoh T. Association of excessive mobile phone use during pregnancy with birth weight: an adjunct study in Kumamoto of Japan Environment and Children's Study. Environ Health Prev Med. 2017;22(01):52. Doi: 10.1186/s12199-017-0656-1

4 Papadopoulou E, Haugen M, Schjølberg S, Magnus P, Brunborg G, Vrijheid M, et al. Maternal cell phone use in early pregnancy and child's language, communication and motor skills at 3 and 5 years: the Norwegian mother and child cohort study (MoBa). BMC Public Health. 2017;17(01):685. Doi: 10.1186/s12889-017-4672-2

5 Birks L, Guxens M, Papadopoulou E, Alexander J, Ballester F, Estarlich $\mathrm{M}$, et al. Maternal cell phone use during pregnancy and child behavioral problems in five birth cohorts. Environ Int. 2017;104:122-131. Doi: 10.1016/j.envint.2017.03.024

6 Shirai T, Wang J, Kawabe M, Wake K, Watanabe SI, Takahashi S, et al. No adverse effects detected for simultaneous whole-body exposure to multiple-frequency radiofrequency electromagnetic fields for rats in the intrauterine and pre- and post-weaning periods. J Radiat Res (Tokyo). 2017;58(01):48-58. Doi: 10.1093/jrr/rrw085

7 Choi KH, Ha M, Ha EH, Park H, Kim Y, Hong YC, et al. Neurodevelopment for the first three years following prenatal mobile phone use, radio frequency radiation and lead exposure. Environ Res. 2017;156:810-817. Doi: 10.1016/j.envres.2017. 04.029

8 Sudan M, Olsen J, Arah OA, Obel C, Kheifets L. Prospective cohort analysis of cellphone use and emotional and behavioural difficulties in children. J Epidemiol Community Health. 2016;70(12): 1207-1213. Doi: 10.1136/jech-2016-207419

9 Divan HA, Kheifets L, Obel C, Olsen J. Prenatal and postnatal exposure to cell phone use and behavioral problems in children. Epidemiology. 2008;19(04):523-529. Doi: 10.1097/EDE.0b013e318175dd47

10 Divan HA, Kheifets L, Obel C, Olsen J. Cell phone use and behavioural problems in young children. J Epidemiol Community Health. 2012;66(06):524-529. Doi: 10.1136/jech.2010.115402

11 Zarei S, Mortazavi SM, Mehdizadeh AR, Jalalipour M, Borzou S, Taeb S, et al. A challenging issue in the etiology of speech problems: the effect of maternal exposure to electromagnetic fields on speech problems in the offspring. J Biomed Phys Eng. 2015;5(03):151-154

12 Vrijheid M, Martinez D, Forns J, Guxens M, Julvez J, Ferrer M, et al. Prenatal exposure to cell phone use and neurodevelopment at 14 months. Epidemiology. 2010;21(02):259-262. Doi: 10.1097/ EDE.0b013e3181cb41e0

13 Divan HA, Kheifets L, Olsen J. Prenatal cell phone use and developmental milestone delays among infants. Scand J Work Environ Health. 2011;37(04):341-348. Doi: 10.5271/sjweh.3157

14 Guxens M, van Eijsden M, Vermeulen R, Loomans E, Vrijkotte TG, Komhout $\mathrm{H}$, et al. Maternal cell phone and cordless phone use during pregnancy and behaviour problems in 5-year-old children. J Epidemiol Community Health. 2013;67(05):432-438. Doi: 10.1136/jech-2012-201792

15 Sudan M, Kheifets L, Arah O, Olsen J, Zeltzer L. Prenatal and postnatal cell phone exposures and headaches in children. Open Pediatr Med J. 2012;6(2012):46-52. Doi: 10.2174/1874309901206010046

16 Baste V, Oftedal G, Møllerløkken OJ, Mild KH, Moen BE. Prospective study of pregnancy outcomes after parental cell phone exposure: the Norwegian Mother and Child Cohort Study. Epidemiology. 2015;26(04):613-621. Doi: 10.1097/EDE.000000000000029

17 Bellieni CV, Pinto I. Fetal and neonatal effects of EMF [Internet]. BioInitiative Working Group; 2012 [cited 2020 Jul 12]. Available from: https://bioinitiative.org/wp-content/uploads/pdfs/sec19_2012_ Fetal_neonatal_effects_EMF.pdf

18 Kühn S, Cabot E, Christ A, Capstick M, Kuster N. Assessment of the radio-frequency electromagnetic fields induced in the human body from mobile phones used with hands-free kits. Phys Med Biol. 2009; 54(18):5493-5508. Doi: 10.1088/0031-9155/54/18/010

19 Leena K, Tomi L, Arja R. Intensity of mobile phone use and health compromising behaviours - how is information and communication technology connected to health-related lifestyle in adolescence? Journal of adolescence. 2005;28(01):35-47

20 Ferraro FR, Holfeld B, Frankl S, Frye N, Halvorson N. Texting/iPod dependence, executive function and sleep quality in college students. Comput Human Behav. 2015;49:44-49. Doi: 10.1016/ j.chb.2015.02.043

21 Mishra RK, Pandey R, Chaki N, Choudhury S, Eds. “NeSen”-a tool for measuring link quality and stability of heterogeneous cellular network. Proceedings of the IEEE International Conference on Advanced Networks and Telecommuncations Systems (ANTS); 2015 Dec 15-18; Kolkata, India. Piscataway: IEEE; 2015. 